\title{
The PhD in Creative Writing and the Teaching thereof at South African Universities
}

Henning Pieterse

\begin{abstract}
The need for and feasibility of a PhD degree in Creative Writing is discussed. The structure and content of PhDs in this field in the UK, USA and Australia are examined. The focus then shifts towards the content and teaching of this $\mathrm{PhD}$ at the four South African universities currently offering it. Recommendations are made in respect of the possible expansion of the institutionalising and teaching of this degree in South Africa.
\end{abstract}

Keywords : Creative Writing PhD, entry criteria, development, structure

\section{Introduction}

In this article, arguments for and against the need for and feasibility of a PhD degree in Creative Writing are discussed. The structure and content of PhDs in this field in the UK, USA and Australia are examined. The focus then shifts towards the content and teaching of this $\mathrm{PhD}$ at the only four South African universities currently offering it, namely the University of KwaZulu Natal (UKZN), the University of the Witwatersrand (Wits), Northwest University (Potchefstroom campus) (NWU) and the University of Pretoria (UP). Recommendations are made in respect of the possible expansion of the institutionalising and teaching of this degree in South Africa.

\section{To $\mathrm{PhD}$ or not to $\mathrm{PhD}$, that is the question}

Although the $\mathrm{PhD}$ in Creative Writing (hereafter $\mathrm{CW}$ ) has been an established degree in the USA (for more than 30 years), the UK and Australia (since the last decade of the previous century) and (since the late 2000's) at a few universities in South Africa (cf. inter alia Harper 2007; Dawson 2007; Pieterse 2013; Holloway 2013 and O'Mahony 2008), Graeme Harper poses the following question and comment:

Doctorates in creative writing: dubious academic "intrusion", or a legitimate higher education activity? It is fair to say that this question has not been answered to everyone's satisfaction. There are those who believe that Doctoral work in creative writing is still worthy of a modicum of scepticism despite - or perhaps even "because of" - a now well-established history of these degrees in Britain and Australia, a history twice as long in North America, and a developing history of them elsewhere. (2007: 345)

According to Harper, such scepticism revolves around notions of how $\mathrm{CW}$ might best be taught, or even whether it can be taught at all. This scepticism draws on examples of successful creative writers who have had little to do with formal higher education. And it connects, in part, "to often strongly-voiced concerns about such things as 'publishability' and 'talent', as well as to anxious commentaries about academe's relationship with creative endeavour; in this case, such an 'intrusion' is even said to be threatening to cause the 'institutionalisation of creative writing' " (345).

Harper poses a further question: "If a Doctoral degree is the highest level of achievement that is, if it represents the most 'steps' confirmed toward expertise - in what has the Doctoral graduate in creative writing achieved the highest university qualification, in what have they 'stepped furthest'?" (346). He adds: "Doctoral study in creative writing cannot merely be 
seen as a way of completing a writing project. A Doctoral degree in creative writing has a more detailed and university 'site-specific' purpose, or set of purposes, and specific intentions" (348).

Nessa O'Mahony, who completed her Masters in CW in 2003, mentions that she was one of the few students in her year group to make the decision to go further with her study. In her experience, the majority of MA students in Creative Writing do not go on to do doctorates. She also cites the high cost of doing a $\mathrm{PhD}$ as a deterrent - a full-time $\mathrm{PhD}$ in the UK costs over 9000 pounds in fees alone.

Scepticism about the feasibility of the $\mathrm{PhD}$ in $\mathrm{CW}$ is eloquently phrased by Marlene van Niekerk, acclaimed poet, short story writer and novelist and professor of Creative Writing at the University of Stellenbosch (US), when she replies as follows to a question posed by Marguerite MacRobert, an American lecturer and doctoral student in CW, regarding whether such doctorates should be acknowledged:

I am aware of so called integrated "creative" doctorates in the Departments of the Visual Arts and in Music at the University of Stellenbosch. At the moment there is no such doctorate in our department for creative writing. In discussions with colleagues at the Music Department, I have always, but to no avail, advised against it, because, in my opinion, it can lead to a huge inflation of academic standards. Five piano performance programmes, playing Schubert pieces, together with a glorified process report, (extensive critical self-reviewing) do not as far as I am concerned constitute a doctorate. The university will no doubt see it as a lucrative business though.

On the other hand I can see how for instance specific historical performance practices of music could be researched and brought to bear on one's own compositions which then also need to be highly innovative and ground breaking, like for instance in the case of somebody like Veljo Tormis and his promotion of the artistic revival of BaltoFinnic shamanistic folk traditions in contemporary classical music. I can imagine that creative people of his ilk would probably scoff at anything to do with universities and could be puzzled by the idea of getting or wanting a doctorate for it.

Quite frankly I think that writers sometimes succeed in writing books that through a confluence of luck, literary quality, and historical circumstances make it into some sort of canon for a while. Sometimes these authors have doctorates in all but literature. I feel that the qualification "Doctor in Creative Writing" is highly doubtful if not inappropriate, apart from sounding satirical. I think that if a novel is worth it academics could under a given set of highly contingent circumstances end up writing doctorates about such novels for several decades or even centuries. The latter seems to me the only way to go as far as the matter of doctorates and works of art are concerned. [ ... ] it could well be that my doubts are entirely unfounded and that I am simply biased! (2013)

MacRobert (2013) engages with these questions as well as with questions regarding entry criteria and criteria for suitability to supervise the doctorate when she states: "What many language departments and schools of creative writing are grappling with is whether there should be an officially designated $\mathrm{PhD}$ in creative writing at all, or whether this should simply be another $\mathrm{PhD}$ within the languages departments. One of the factors here is what constitutes research or scholarship at this level. [ ... ]" 
MacRobert notes that she has heard a former academic saying that the entry criteria for the $\mathrm{PhD}$ should be not only a Masters in $\mathrm{CW}$, but that the student's creative work from this should have been published by a reputable publisher, to great critical acclaim, and that the creative work proposed for the $\mathrm{PhD}$ should then be of a significantly more ambitious scope. Her co-promotor, a professor of CW in the UK, thought this was an impossibly high bar to set, and not in proportion to the entry criteria for other degrees (a sociologist, psychologist or historian applying for a doctorate has to have a decent research proposal and a sufficient level of achievement in their Masters, not an already established reputation in the field). This professor feels that the principle difference between a doctorate and a Masters in CW is the level of scholarship and the depth of research proposed. He, for example, favours dropping the exegesis for a research proposal (cf. MacRobert 2013).

MacRobert further notes that many of South Africa's language departments or writing schools do not have the staff capacity to take on many doctorates (in proportion to the number of MA graduates, or other language doctorates on offer).

From the above, it should be clear that the $\mathrm{PhD}$ in $\mathrm{CW}$ - regarding its feasibility, aims and structure - is still a bone of contention for some academics.

\section{The aim of the $\mathrm{PhD}$ in Creative Writing and possible reasons for undertaking it}

What, then, would the central reasons be for undertaking a $\mathrm{PhD}$ in $\mathrm{CW}$ ?

Harper lists the following reasons why such a doctorate might be undertaken:

- The desire by an experienced writer to explore new forms and styles, not necessarily leading to publication;

- An interest in critical and theoretical investigation of writing product and process;

- Setting in motion an investigation of the learning and teaching connected with creative writing;

- Developing for publication a project involving considerable research in the fields of history and psychology;

- Applying philosophic, cultural and political ideas of various kinds to the production of fiction;

- Investigating the ways in which a collection of poetry might be "held together";

- Working from personal, family history toward broader cultural and historical investigation through prose and poetry; and

- Adopting ideas about narrative to the construction of new forms of digital film script. (2007: 349)

Paul Dawson (2007: 88) also lists a few possible reasons for the undertaking of the $\mathrm{PhD}$ in $\mathrm{CW}$, noting that many established teachers of $\mathrm{CW}$ who were initially hired on the strength of their creative publications have undertaken doctoral study for professional reasons: in order to achieve promotion, or to meet standard requirements that supervisors of doctoral candidates should themselves possess a $\mathrm{PhD}$. He mentions that a growing trend has been for $\mathrm{PhD}$ programmes to accept for candidature well-established writers with national and international literary reputations, many without strong academic backgrounds or any aspirations to work in the academy. 


\section{The development of the PhD in Creative Writing}

The $\mathrm{PhD}$ in $\mathrm{CW}$ is a relatively new degree: in the USA it has been offered by various universities for about 30 years and in the UK and Australia for about 20 years since the 1990's (cf. Whitehead 2013: 98). O'Mahony mentions that, at the time of her application (2004) only 20 universities in the UK ran CW doctoral programmes. Holloway (2013: 140) writes that (in 2013) a PhD was available at around 50 universities in the UK alone - the tremendous growth in the offering of the degree is evident, a growth that Dawson regards as "the most salient feature of Creative Writing in the post-Theory academy" (2007: 87).

Harper (2007) and Dawson (2007) provide brief "histories" of the development of the MA and $\mathrm{PhD}$ in $\mathrm{CW}$. Harper writes that early UK Masters courses in CW often emerged not from a sense of progression from Bachelor onwards to Doctor, but from a particular version of an “"artist-at-work' ideal, often built on entirely local and personal interpretations of what this might entail” (347).

Dawson also provides a good background to the development of this $\mathrm{PhD}$. He regards the growth of the degree as important because "the sort of doctoral education provided to a new generation of teachers will not only define Creative Writing as a research-based discipline, but also determine the future direction of the way the subject is taught at all levels" (2007: 87-88). In accordance with Ritter (2001), Dawson views this $\mathrm{PhD}$ as an important additional degree for MFA graduates who hope to teach in academe.

Ritter (2001, as quoted by Dawson 2007: 87) argues that the PhD should be reconfigured towards teacher training, and Bizarro (2004, as quoted by Dawson 2007: 87) writes that if $\mathrm{CW}$ is to operate as a discipline in its own right it must offer a distinct doctoral degree; this would then involve the systematic teaching of skills employed by writers which are equivalent or analogous to those of scholarly research, and it would involve the teaching of skills required by writing teachers. For Ritter and Bizarro, $\mathrm{PhD}$ candidates then need to be provided with discipline specific skills rather than those offered by standard doctoral courses in literary research and composition teaching.

\section{The structure of the PhD in the UK, USA and Australia}

In North America, the Association of Writers and Writing Programs (AWP) has favoured as "terminal degree" for creative writers who want to work in academe the MFA degree, but, as Harper (2007: 348) argues, the MFA is fundamentally not about a developed and articulated critical response to creative output in the way that a CW Doctorate in Britain and Australia promotes - the MFA differentiates itself from Doctoral study by de-emphasising a formalised critical response and emphasising creative activity. Even so, Doctoral study in CW does exist in North America and Doctorates (with an emphasis on coursework in literature or history and culture or theory) are awarded in that field (cf. Harper 2007: 348-9).

Katharine Coles (2006: 10) writes, for example, that students enrolled for the $\mathrm{PhD}$ taught at Utah University take more than half their coursework in literature and critical theory. Because the scholarly component of their $\mathrm{PhD}$ is strenuous, they recruit students who demonstrate serious commitment to literary study in addition to creative work, as well as literature and theory faculty who commit themselves to literary study. Still, their students struggle to divide themselves between two competing, apparently disparate pursuits. Though 
they believe intuitively that their scholarly work and their creative work are related, they are not sure how, and their educations do not help them clarify matters.

The Doctoral degree in the UK tends to combine both creative and critical work, where the creative is usually the greater proportion, and the critical component (the thesis, the critical response, the dissertation or (in Australasia) the exegesis) responds to and further articulates the nature of the explorations undertaken in the creative work. In the UK and Australia, Doctoral study appears much like a lengthier version of research-orientated MA study in CW, but whereas Doctorates in the UK draw strongly on the discourses of research in English Literature, in Australia the range of "inter-discliplinary" influences is wider (Harper 2007: 349).

Dawson (2007: 88) regards the $\mathrm{PhD}$ in $\mathrm{CW}$ as a more widespread option in Australian universities, which Krauth (2001) views as "international pioneers in developing the creative writing doctorate". The reasons for the growth of this option (cf. Holloway (2013) and O'Mahony (2008) in this regard) are partly economic, because "in the modern university the $\mathrm{PhD}$ is now an essential academic qualification for aspiring teachers; and universities are keen to enrol large numbers of students because they attract research funding" (Dawson 2007: 88, also cf. Van Niekerk's (2013) comment on a "lucrative business" in this regard).

Dawson also mentions that the debates over the $\mathrm{PhD}$ in Australia and the UK have differed from those in America because the degree structure itself is different: in America, as mentioned above, doctoral students must complete substantial coursework and language requirements as well as sitting for examinations before submitting their dissertations, while in the UK and Australia there is no formal coursework and the degree is accessible by thesis only (2007: 88). This thesis consists of a creative dissertation and a substantial critical essay (the "exegesis"), of up to 50\% of the word limit. This model comes from "research degrees in the visual and performing arts [cf. Van Niekerk's (2013) criticism of this model again], where a formal reflection on the creative process provides an interpretive guide to examiners for ephemeral performances or non-verbal artefacts" (88).

Holloway (2013: 130) emphasises the fact that the prevailing British understanding of CW research appears to see it as being practice-led research and continues: "[T]he research is by and large led by the creative acts themselves [... ]. The writing comes first, and this awareness leads everything that Creative Writing researchers [ ... ] do. More than that, the writing is the research". The methods of study focus not on the post-textual examination of others' work, but on the intra-textual work of the student (131). For Holloway, the greatest benefit for a writer in completing a PhD in $\mathrm{CW}$ is "not the development of a new researcher, publishing learned articles and books, but the knowledge gained through investigations of and through process [ ... ]" (2013: 142).

\section{The South African experience in teaching the $\mathrm{PhD}$ in Creative Writing}

Pieterse (2013) found that, while there are 11 South African universities offering the MA in $\mathrm{CW}$ (via language departments or not), only four are currently offering the PhD: the University of KwaZulu Natal, the University of the Witwatersrand, Northwest University (Potchefstroom campus) and the University of Pretoria. The final section of this article will explore the nature and structure of the PhDs offered by these four institutions. 


\subsection{The University of KwaZulu-Natal}

Poet and playwright Kobus Moolman, senior lecturer in English and coordinator of CW at UKZN, writes that this university has not had much experience with the $\mathrm{PhD}$ - there have only been four degrees awarded to date since the inception of the degree (2004), including his own. He wrote a long multi-genre cycle of poems for the creative dissertation. His view on the structure of the $\mathrm{PhD}$ is similar to that of Harper (2007):

[T] he way I have envisaged the $\mathrm{PhD}$ is that it is there essentially to take an already established (how established can be debated and discussed) writer forward. To take them to a new level in their own work. To break new ground for them. To challenge their own work. So that they are not just writing another piece of creative writing (which someone can do for their MA), but that they are involved with researching and investigating and testing new, hitherto unexplored, forms of creative practice and knowledge. (2014)

Regarding selection criteria for the $\mathrm{PhD}$, Moolman writes:

Our selection criteria for the $\mathrm{PhD}$ is that it is only open to candidates who have already demonstrated some degree of writing ability and proficiency. Usually, this is through a record of publications, awards, residencies, and such. At the moment all the people thus far who have done the degree have had a Masters degree, so while this is not a strict requirement, it is nevertheless a recommendation since the candidate will be required to produce a substantial piece of critical/analytical writing. (2014)

The format of the UKZN PhD follows the two-fold structure as outlined by Harper (2007), Dawson (2007), Holloway (2013) and O'Mahony (2008): an extended creative manuscript and an exegesis/thesis. Moolman comments on this as follows:

Of course, the dilemma is that this is the same structure for the MA. Although I notice that not all SA institutions have the thesis as part of their MA. But I think that for some the MA is part coursework, part final creative project. We at UKZN have no coursework for the MA or PhD in English Studies (which creative writing falls under). The degrees are solely by supervision. One on one consultations with a supervisor. Which I favour-but of course is very time-consuming. (2014)

He regards the $\mathrm{PhD}$ as being

ultimately just longer, more in-depth, more challenging. Just more, more. Longer. In other disciplines of course the $\mathrm{PhD}$ has the ryder that it must make an original contribution to research/knowledge. Well, it is tricky in any of the performative disciplines where by their very nature they are producing original material, and making an original contribution. So again, we come around to the distinction between the MA and the $\mathrm{PhD}$-which is, while not problematic, then let us just say slippery. (2014)

On his own experience in completing a $\mathrm{PhD}$, Moolman writes:

My experience with the $\mathrm{PhD}$ has coloured my sense of its place in the university [... ]. It was for me a fundamentally changing and enlarging experience. [ ... I I was largely left to my own devices. Which suited me fine, because I kind of knew what I wanted to do-although of course I did not know how to do it, and only found this out 
along the way. [... ] Now, the question is, would a MA degree have provided the same result? [...] There ultimately was something different about the focus, the intensity, the extent of the engagement with my already existent work and my existent ideas and forms, that was somehow different. A difference in degree, not kind. [ ... ] Does it warrant the $\mathrm{PhD}$ degree? Well, I do think so. If only because of what it has the potential of unlocking. (2014)

\subsection{The University of the Witwatersrand}

At Wits, the PhD in CW (date of inception: 2012) is undertaken over a minimum period of two years. It comprises a creative project that may take the form of a performance and/or a body of creative work (novel, collection of stories/essays, etc.) plus a dissertation that contextualises the work critically and defends its originality. These two parts of the $\mathrm{PhD}$ constitute the thesis and are examined as a whole.

A candidate for a $\mathrm{PhD}$ in $\mathrm{CW}$ should have published at least one book of writing through a reputable, independent publisher, in a creative-writing genre, of a standard consonant with entry to a $\mathrm{PhD}$ programme as rated by peer review (newspaper and/or journal reviews and/or expert opinion solicited by the Coordinator of the $\mathrm{PhD}$ in $\mathrm{CW}$ ). This portfolio of published work must be of such a standard as to justify the admission of a candidate to a $\mathrm{PhD}$ programme in which a $\mathrm{CW}$ project, and a reflexive commentary (dissertation) on the work, of a PhD standard will be required from the candidate (cf. Law-Viljoen 2012).

Bronwyn Law-Viljoen, coordinator of Creative Writing at Wits, writes that there must be a coherent relationship between the creative work and the dissertation, so that the two components can be assessed as an integrated whole. The dissertation must serve to contextualise the creative work critically and enable the examiners to assess its originality. In the research proposal as well as the dissertation the candidate must demonstrate how the scholarly work informs and elucidates the creative work (2012).

The creative work must be the equivalent of a year's full-time work. The research proposal should explain the creative work and indicate why it is of appropriate scope. If the creative work has a smaller scope than the norm (one year of full-time work), the proposal must indicate why this is so and what proportion of the overall effort would be dedicated to it.

Assessment criteria for the $\mathrm{PhD}$ at Wits are:

- The creative component of the $\mathrm{PhD}$ must be a significant and coherent undertaking, for example a full-length novel, a substantial collection of short stories or poems, a full-length book of creative nonfiction, a film or play script, showing a level of complexity, originality and density that is consonant with the demands of a $\mathrm{PhD}$.

- The thesis as a whole (that is the creative work plus reflexive dissertation) must make an original and intellectually articulate contribution to the understanding of contemporary literary art.

- The creative work must be contextualised in relation to other forms of literary and/or cultural production and contribute to the advancement of the discipline and critical debate in the field.

- The creative work must exemplify and locate ideas in conjunction with the reflexive dissertation. 
- The candidate's research is expected to focus on one or more of the following: a critical exploration of the history, theory and practice of written creative art; the relationship between written creative art and society; the relationship between written creative art and other disciplines and/or other forms of art.

- The reflexive dissertation should be between 30,000 and 40,000 words.

In summary, Wits regards the $\mathrm{PhD}$ as "a thesis, the research for which is normally conducted under the guidance of a supervisor, which must constitute, in the opinion of the Senate, a substantial contribution to the advancement of knowledge in the subject chosen, and which must be satisfactory as regards literary presentation" (Law-Viljoen 2012).

\subsection{Northwest University}

The $\mathrm{PhD}$ in $\mathrm{CW}$ is currently offered by the Department of Afrikaans-Dutch at NWU (Potchefstroom campus). It is envisaged that this degree (as well as the MA) will in the future be acknowledged as independent qualifications.

The PhD at NWU is a research-based degree. Students work on their own under supervision. The focus is more on the development of the student as independent researcher and writer and not on the development of manuscripts as such. In general a practice-led approach is followed. The relationship and balance between theory and creative writing depends on the specific research topic and the background of the student (cf. Greyling 2012).

\subsection{The University of Pretoria}

The structure of this degree at UP (date of inception: 2007) is also two-fold (a creative manuscript of extended scope in any literary genre plus a research-based thesis), but allows for more than a self-reflexive and/or practice-based approach: the thesis/exegesis (as at UKZN) could be practice-led (as at NWU) and there could be a coherent relationship between the creative work and the dissertation, so that the two components can be assessed as an integrated whole and where the dissertation serves to contextualise the creative work critically (as at Wits). Alternatively, the candidate may write a thesis on a literary, theoretical or comparative literary topic, with or without reference to the creative component.

Prospective students must hold an MA and a rigorous selection process is followed to ascertain whether the candidate will also be able to tackle the thesis/exegesis part successfully. Candidates must have published at least one book with a reputable publisher; literary awards and accolades may be taken into consideration.

At the time of writing, five students were working on their PhDs at UP (another two have previously completed the degree). All these students have published at least one book (in two cases, students have already published three books) and could prove their research capabilities to the selection committee (mostly by way of research conducted for their MA's).

\section{Conclusion}

The level of scholarship and depth of research proposed seem to be focal points when discussing the nature, structure and focus of the $\mathrm{PhD}$ in $\mathrm{CW}$. Harper focuses on these points when he summarises the nature of the (ideal) $\mathrm{PhD}$ in an excellent fashion: 
The conceptual thrust of creative writing Doctorates is such that they encourage a writer to delve more widely and deeply into knowledge of their field, and to show this clearly. Their intention is to contribute both to the development of the individual writer and to the holistic site of knowledge and engagement with the world that is defined by the term "creative writing". The primary word here is "understanding", and the primary intention is both creation and articulation. (2007: 350)

He convincingly answers the question what someone studying for a Doctorate in $\mathrm{CW}$ is seeking to accomplish or should be seeking to accomplish: "[ ... ] a level and display of understanding in relation to creative writing process, practice and product that can be seen by experts in the field to be equivalent to, though not the same as, performance of Doctoral candidates in other fields" (351).

Based especially on Harper (2007), Dawson (2007) and Holloway's (2013) motivations and statistics, it seems clear that, despite a modicum of scepticism from certain academic quarters, doctorates in Creative Writing are being accepted more and more and the number of universities offering this degree is increasing rapidly in especially English-speaking academia.

The South African $\mathrm{PhD}$ in $\mathrm{CW}$, having been introduced only in the late 2000 's, is still in its infancy - only nine PhDs have been delivered at Wits, UP, UKZN and NWU (compared to more than 110 MA's delivered - cf. Pieterse 2013). South African universities therefore lag behind their counterparts in the UK, USA and Australia in this aspect and the expansion of this $\mathrm{PhD}$ should be encouraged at more South African universities, especially for candidates wishing to pursue careers as lecturers in $\mathrm{CW}$ by acquiring the teaching of skills required by writing teachers. As mentioned above, NWU is currently busy implementing a doctorate in $\mathrm{CW}$, but other universities offering $\mathrm{CW}$ should also be encouraged to adopt the degree, since $\mathrm{CW}$ as field (in both teaching and research) is burgeoning in the country and because more and more universities demand a PhD qualification from their lecturers (cf. Pieterse 2013).

As can be gleaned from the above, the South African PhD is closer in structure to the UK and Australian $\mathrm{PhD}$ than to the American version - there is no coursework involved, but a thesis/exegesis.

The author of this article feels strongly that authors like Harper (2007) and Dawson (2007) make excellent arguments for the creation and expansion of this degree and that their points of view should gain a wider audience world-wide.

Ultimately, the debates on the structuring of the PhD in $\mathrm{CW}$ are not only about doctoral education, but, as Dawson writes, "about how Creative Writing defines itself as an academic discipline in the New Humanities. The future of the discipline hence resides in how it theorises and manages the traditional nexus between research and teaching in the modern university" (2007: 88).

\section{References}

1. Bizarro, Patrick. 2004. "Research and Reflection in English Studies: the Special Case of Creative Writing." College English 66 (3): 294-309. doi: 10.2307/4140750

2. Coles, Katharine. 2006. "Short Fiction.” In: Harper, Graeme (ed). Teaching Creative Writing. London \& New York: Continuum. 
3. Dawson, Paul. 2007. "The Future of Creative Writing. In: Earnshaw, Stephen (ed). The Handbook of Creative Writing. Edinburgh: Edinburgh University Press: 78-89.

4. Greyling, Franci. 2012 e-mail, 30 July.

5. Earnshaw, Stephen (ed). 2007. The Handbook of Creative Writing. Edinburgh: Edinburgh University Press.

6. Harper, Graeme (ed). 2006. Teaching Creative Writing. London \& New York: Continuum.

7. Harper, Graeme. 2007. “Creative Writing Doctorates.” In: Earnshaw, Stephen (ed). The Handbook of Creative Writing. Edinburgh: Edinburgh University Press.

8. Harper, Graeme and Jeri Kroll (eds). 2008. Creative Writing Studies: Practice, Research and Pedagogy. Clevedon, Buffalo, Toronto: Multilingual Matters Ltd.

9. Harper, Graeme (ed). 2013a. A Companion to Creative Writing. London: John Wiley \& Sons, Ltd.

10. Harper, Graeme (ed). 2013b. New Ideas in the Writing Arts: Practice, Culture, Literature. Cambridge: Cambridge Scholars Publishing.

11. Holloway, Simon. 2013. "How to Make a Pocket Watch: The British Ph.D. in Creative Writing." In: Harper, Graeme (ed). A Companion to Creative Writing. London: John Wiley \& Sons, Ltd.

12. Krauth, Nigel. 2001. "The Creative Writing Doctorate in Australia: An Initial Survey." TEXT: The Journal of the Australian Association of Writing Programs 5(1), April.

http://www.textjournal.com.au/speciss/issue1/content01.htm. [Accessed: 15 January 2015].

13. Law-Viljoen, Bronwyn. 2012. e-mail, 13 August.

14. MacRobert, Marguerite. 2013. e-mail, 25 February.

15. Moolman, Kobus. 2014. e-mail, 3 December.

16. O'Mahony, Nessa. 2008. "That Was the Answer: Now What Was the Question? The PhD in Creative and Critical Writing: A Case Study.” In: Harper, Graeme \& Jeri Kroll (eds). Creative Writing Studies: Practice, Research and Pedagogy. Clevedon, Buffalo, Toronto: Multilingual Matters Ltd.

17. Pieterse, Henning. 2013. "Die dosering van Skryfkuns aan Suid-Afrikaanse universiteite: "n Oorsig." ("Teaching Creative Writing at South African universities: An Overview.") Literator 34 (2): 1-12. doi: 10.4102/lit.v34i2.421

18. Ritter, Kelly. 2001. "Writing Professionals/Professional Writers: Revamping Teacher Training in Creative Writing Ph.D. Programs." College English 64 (2): 205-227. doi: 10.2307/1350117

19. Van Niekerk, Marlene. 2013. e-mail, 25 February. mvn4@sun.ac.za.

20. Whitehead, Harry. 2013. "Nomadic Emergence: Creative Writing Theory and Practice-Led Research.” In: Harper, Graeme (ed). New Ideas in the Writing Arts: Practice, Culture, Literature. Cambridge: Cambridge Scholars Publishing. 